\title{
Chemical Composition and Biological Activities of The Essential Oil And Anatomical Markers Of Lavandula Dentata L. Cultivated In Brazil
}

\author{
Barbara Justus $^{1 *}$, Valter Paes de Almeida ${ }^{1}$, Melissa Marques Gonçalves ${ }^{2}$, Daniele Priscila \\ da Silva Fardin de Assunção ${ }^{1}$, Debora Maria Borsato', Andres Fernando Montenegro \\ Arana $^{1}$, Beatriz Helena Lameiro Noronha Sales Maia ${ }^{2}$, Josiane de Fátima Padilha de \\ Paula $^{1}$, Jane Manfron Budel ${ }^{1}$, Paulo Vitor Farago ${ }^{1}$ \\ ${ }^{1}$ Universidade Estadual de Ponta Grossa, Ponta Grossa, Paraná, Brazil; ${ }^{2}$ Universidade Federal do Paraná, \\ Curitiba, Paraná, Brazil
}

\begin{abstract}
Lavandula dentata, popularly known as lavender, is commonly used in traditional medicine for the treatment of digestive and inflammatory disorders. The objective of this study was to analyzed the chemical oil composition, antioxidant and antimicrobial activities of the essential oil and anatomical markers of the leaf and stem of L. dentata cultivated in South Brazil. Essential oil showed an antioxidant activity similar to rutin and gallic acid when analyzed by phosphomolybdenum method. However, by the free radical DPPH and ABTS methods, it showed a slight potential antioxidant. Essential oil presented 1,8-cineol (63\%) as major component, antimicrobial activity against Gram-positive, Gram-negative bacteria strains and Candida albicans, by broth microdilution. The anatomical profile provided the following main microscopic markers: hypostomatic leaves; diacytic stomata, thin and striate cuticle; multicellular and branched non-glandular trichomes; capitate glandular trichomes; peltate glandular trichomes; dorsiventral mesophyll; flat-convex shape midrib, truncated on the abaxial side; one collateral vascular bundle in the midrib; square stem shape, angular collenchyma alternated with cortical parenchyma; sclerenchymatic fibers well-developed on the four edges.
\end{abstract}

Keywords: Anatomy.Antimicrobial. Antioxidant.Lamiaceae. Quality control. Volatile oil.

\footnotetext{
* Author for correspondence: barbara.justus@ hotmail.com
} 


\section{INTRODUCTION}

In several civilizations, the use of medicinal plants survived the technological development and is currently the subject of numerous scientific research for the treatment of different pathologies. The Brazilian ecosystem provides material for the study of new drugs due to its great diversity with high therapeutic potential ${ }^{1,2}$. Some compounds used in treatments may be derived or analogs to a plant compounds ${ }^{3}$ or can also be used as a prototype for the development of new substances ${ }^{4}$.

Several activities have been reported for Lavandula L., such as antimicrobial, antioxidant and anti-inflammatory ${ }^{5,6}$. These activities are related by the presence of several chemical constituents of essential oil, such as ethyl linalool, fenchone, linalool, $\alpha$-terpineol, 1,8-cineole and camphor. These last both components presented antispasmodic, antifungal, antibacterial, anti-inflammatory, analgesic, repellent and insecticide properties ${ }^{7-9}$.

Lavandula dentata $\mathrm{L}$. is popularly known as lavender and it is a medicinal plant used in the traditional medicine as an antidiabetic, antispasmodic, anti-hypertensive against common flu and renal colic. It is also used in the ornamentation and as a melliferous plant ${ }^{8-14}$.

Two problems are linked with medicinal and herbal drug plants, the adulteration and tampering ${ }^{15,16}$. For species of Lavandula is even worse because they have great hybridization capacity and morphological diversity that makes difficult to identify them ${ }^{17}$. Another important problem is the folk name, several species are known by popular lavender or alfazema names and are used for the same therapeutic purposes $18,19,10$.

Considering the therapeutic potential of $L$. dentata, this study aims to perform a micromorphology characterization, chemical composition microbiological and antioxidants assays of essential oil of L. dentata, contributing to the development of herbal products, derivatives, analogues or prototypes of new substances for treatment of various diseases; besides, supply the anatomical markers of the leaves and stems to support the species identification.

\section{MATERIAL AND METHODS}

\section{Botanical Material}

Lavandula dentata L. was collected at the Botanical Garden of Pharmacy course in the State University of Ponta Grossa (latitude $25^{\circ} 5^{\prime} 23^{\prime \prime S}$ and longitude $50^{\circ} 66^{\prime 2} 3^{\prime \prime} \mathrm{W}$ ), Paraná, South Brazil, in December, 2015. The dried material was identified and the voucher was registered under number 390597, at the Herbarium of Botanical Museum of Curitiba.

\section{Extraction of essential oil (EO) of Lavandula dentata L.}

The EO was extracted and determined quantitatively from $100 \mathrm{~g}$ of dried leaves and stems of the species. The extraction was performed by hydrodistillation, using the Clevenger apparatus ${ }^{20}$, lasting $6 \mathrm{~h}$. After this time, it was determined EO content extracted by direct measurement on the graduated tube. The EO was dried with anhydrous sodium sulfate and stored in sealed glass vials with Teflon caps at $4 \pm$ $0.5^{\circ} \mathrm{C}$ in the absence of light until use. The analysis of volatile compounds from EO was carried out at Federal University of Paraná. 


\section{Gas Chromatography-Mass Spectrometry (GC/MS) analysis}

The identification of volatile constituents was performed using a gas chromatograph (GC) Hewlett-Packard 6890 equipped with a mass selective detector (MS) 5975, and Hewlett-Packard HP-5 capillary column ( $30 \mathrm{~m}$ x $0.25 \mathrm{~mm} \times 0,25 \mu \mathrm{m})$. GC-MS was performed with an injection volume of $1 \mathrm{~mL}$ in split mode (ratio 1:10) the injection port was set at $250{ }^{\circ} \mathrm{C}$, adjusted to $60{ }^{\circ} \mathrm{C}$ column, with a heating ramp of $3{ }^{\circ} \mathrm{C} \cdot \mathrm{min}^{-1}$, final temperature $240{ }^{\circ} \mathrm{C}$ and an interface temperature was set at $300^{\circ} \mathrm{C}$. Helium was used as carrier gas at $1 \mathrm{~mL} \cdot \mathrm{min}^{-1}$. The electron ionization GC-MS system was $70 \mathrm{eV}$. The quantitative analysis was performed using a gas chromatograph Hewlett-Packard 5890 equipped with a flame ionization detector (FID) under the same conditions described above.

Essential oil was dissolved in ethyl acetate $\left(1 \mathrm{mg} \cdot \mathrm{mL}^{-1}\right)$ for analysis. The retention index (RI) was determined by injecting a homologous series of $n$-alkanes standards and $\mathrm{EO}$ of $L$. dentata under the same conditions. The volatile components were identified by comparison with the literature data (Adams, 2007) and the profiles of the mass spectra libraries (Wiley 139, 275, 127 and NIST 7). Quantitation was obtained using GC-FID was expressed as average of three samples extracted from the EO.

\section{Antimicrobial Activity}

Minimal Inhibitory Concentration (MIC) and Minimal Bactericidal Concentration $(M B C)$.

By the microdilution broth method proposed by NCCLS ${ }^{21}$, the bacteria were inoculated in BHI (brain heart infusion) broth, with an adjusted concentration of microorganisms in 0.5 McFarland for Staphylococcus aureus ATCC $^{\circledR}$ 25923, Escherichia coli ATCC $^{\circledR}$ 25922, Pseudomonas aeruginosa ATCC $^{\circledR}$ 9027, Streptococcus pyogenes ATCC ${ }^{\circledR} 19615$. The same methodology was used for Candida albicans ATCC $^{\circledR}$ 10231, replacing the medium culture by Sabouraud broth. Microplates containing the inoculum in contact with EO at the concentrations of $437.5 ; 218.8 ; 109.4 ; 54.7$ e $27.3 \mu \mathrm{g} / \mathrm{mL}$, were incubated in bacteriological incubator at $35^{\circ} \mathrm{C}$ and the microbial growth was observed after $24 \mathrm{~h}$ of incubation. The minimum inhibitory concentration (MIC) was visually determined using the 2,3,5triphenyltetrazolium chloride (TTC). After $30 \mathrm{~min}$, the wells with microbial growth were red stained ${ }^{22}$. The well contents where the minimum concentration of the sample restrained the growth was transferred to a petri plate having BHI agar or Sabouraud on it. The plates were incubated at $35^{\circ} \mathrm{C}$ for $24 \mathrm{~h}$. The detection of microbial presence on the plate indicated that the sample does not have the ability to inhibit the growth, whereas microbial absence indicates that the sample has ability to induce cell death of the microorganisms and determined the minimum bactericidal concentration (MBC).

\section{Antioxidant Activity}

$D P P H \bullet(2,2-d i f e n i l-1-p i c r i l-h i d r a z i l a)$

The scavenging activity of EO for the radical 2,2-diphenyl-1-picrylhydrazyl (DPPH) was measured as described by Yen and Wu (1999) ${ }^{23}$ and Chen et al. (2003) ${ }^{24}$. Briefly, samples in different concentrations were previously diluted in methanol. A volume of $300 \mu \mathrm{L}$ of a $0.5 \mathrm{mmol}^{-1} \mathrm{DPPH}$-ethanol solution was added to $3 \mathrm{~mL}$ of ethanol and 500 $\mu \mathrm{L}$ of sample dilution. The samples were kept at room temperature in the dark. After 
$30 \mathrm{~min}$, the absorbance values were measured at $517 \mathrm{~nm}$ and converted into the percentage antioxidant activity by Equation 1.

Equation 1. Percentage antioxidant activity by DPPH $\bullet$

A: absorbance value

$$
\% \text { inhibition DPPH } \bullet=100-\frac{\left(A_{\text {sample }}-A_{\text {blank }}\right)}{A_{\text {control }}}
$$

\section{Phosphomolybdenum Complex}

In the phosphomolybdenum complex assay ${ }^{25,}{ }^{26}$, the complex was formed by the reaction of $\mathrm{Na}_{3} \mathrm{PO}_{4}$ solution $(0,1 \mathrm{~mol} / \mathrm{L})$ with $\left(\mathrm{NH}_{4}\right)_{6} \mathrm{Mo}_{7} \mathrm{O}_{24} .4 \mathrm{H}_{2} \mathrm{O}(0,03 \mathrm{~mol} / \mathrm{L})$ and $\mathrm{H}_{2} \mathrm{SO}_{4}$ solution ( $3 \mathrm{~mol} / \mathrm{L}$ ), in aqueous medium. Essential oil was diluted in ethanol to a concentration of $200 \mu \mathrm{g} / \mathrm{mL}$, even ascorbic acid $\left(\right.$ Merck $\left.^{\circledR}\right)$, gallic acid $\left(\right.$ Merck $\left.^{\circledR}\right)$ and rutin $\left(\right.$ Merck $\left.^{\circledR}\right)$. The blank was ethanol and the reagent. The tubes were hermetically sealed and taken to a water bath at $95^{\circ} \mathrm{C}$ for 90 min. After cooling, the absorbance reading (A) was performed in a spectrophotometer (UV/Vis SHIMADZU-1601) at $695 \mathrm{~nm}$. For determination of antioxidant activity relative to ascorbic acid was determined in percentage (\%AAR) using the Equation 2. The antioxidant activity of rutin and gallic acid was calculated using the same equation.

Equation 2. Percentage of antioxidant activity relative to ascorbic acid.

$$
A A R \%=\frac{A_{\text {sample }}-A_{\text {blank }}}{A_{\text {ascórbic ácid }}-A_{\text {blank }}} \times 100
$$

ABTS $\bullet^{+}$Radical (2,2-azinobis-[3-etil-benzotiazolin-6-sulfonic acid])

Aqueous solutions of ABTS ${ }^{+}\left(7 \mathrm{mmol} . \mathrm{L}^{-1}\right)$ and potassium persulfate $\left(2,45 \mathrm{mmol} . \mathrm{L}^{-1}\right)$ were prepared in a volumetric ratio of 1:1 and incubated at room temperature away from light for $12 \mathrm{~h}$ to obtain the ABTS $\bullet+{ }^{27}$. This solution was diluted at $50 \mathrm{mmol} . \mathrm{L}^{-1}$ in a solution of sodium phosphate buffer $\mathrm{pH} 7,4$. Dilutions of EO, rutin $\left(\right.$ Merck $\left.^{\circledR}\right)$ and gallic acid $\left(\right.$ Merck $\left.^{\circledR}\right)$ was prepared in ethanol $\left(20,15,10\right.$ e $\left.5 \mu \mathrm{g} \cdot \mathrm{mL}^{-1}\right)$. An aliquot (10 $\mu \mathrm{L})$ of the samples and standards were placed whit the reagent $(190 \mu \mathrm{L})$ and incubated in the dark for $30 \mathrm{~min}$. The reading of absorbance (A) was performed in a plate reader (Biotek, $\mu$ Quant) at $734 \mathrm{~nm}$. The Equation 3 was used for calculation of antioxidant activity (AA).

Equation 3. Percentage of antioxidant activity by ABTS $\bullet{ }^{+}$.

$$
\% A A=100-\left(\frac{A_{\text {sample }}-A_{\text {blank }}}{A_{\text {reagent }}}\right) \times 100
$$

\section{Microscopic procedure}

Leaf and stem fragments were fixed in FAA $70{ }^{28}$ and maintained in $70 \%$ ethanol solution ${ }^{29}$. Transversal freehand sections were stained either with basic fuchsine and Astra blue combination ${ }^{31}$. Histochemical reactions were applied with ferric chloride to detect phenolic compounds ${ }^{30}$, Sudan III to lipophilic substances ${ }^{31}$ and phloroglucinol/ $\mathrm{HCl}$ to lignified elements ${ }^{32}$. The results were illustrated with photos taken by the optical microscope Olympus CX31 attached to the control unit C7070.

For the field emission scanning electron microscopy (FESEM) Mira 3 Tescan was used. Plant material was performed using high vacuum with high accelerating voltage $(15 \mathrm{kV})$. Fixed leaves and stems were sectioned and passed through a series of ethanol 
solutions $(80 \%, 90 \%$ and $100 \%)$ and then dried in a critical point dryer. After, the samples were submitted to metallization with gold (Quorum, modelo SC7620). This analysis was conducted in c-LABMU/PROPESP, at the State University of Ponta Grossa (UEPG), Paraná, Brazil.

\section{RESULTS AND DISCUSSION}

\section{Chemical composition of essential oil}

Essential oils are complex mixtures of monoterpenoids $\left(\mathrm{C}_{10}\right)$ and sesquiterpenoids $\left(\mathrm{C}_{15}\right)$. In addition, may present small amounts of diterpenes, arylpropanoids, smaller molecules, such as alcohols, aldehydes and short chain of ketones ${ }^{33-35}$. The main compounds identified by comparing the theoretic retention index calculated for EO from aerial parts of L. dentata are described in the Table 1.

Table 1. Chemical composition of essential oil of L. dentata.

\begin{tabular}{c|c|c|c|c}
\hline Compound name & $\begin{array}{c}\text { Molecular weight } \\
\left(\mathrm{g} . \mathrm{mol}^{-1}\right)\end{array}$ & $\begin{array}{c}\text { Calculated } \\
\text { retention index }\end{array}$ & $\begin{array}{c}\text { Literature } \\
\text { retention index }\end{array}$ & Concentration (\%) \\
\hline Isolimonene & 136.2340 & 980 & 980 & 6.96 \\
\hline $1,8-$ cineole & 154.249 & 1034 & 1026 & 63.25 \\
\hline Linalol & 154.25 & 1100 & 1095 & 3.70 \\
\hline Trans-pinocarveol & 152.23 & 1142 & 1135 & 5.65 \\
\hline Trans-verbenol & 152.2334 & 1150 & 1140 & 2.69 \\
\hline Ment-3-en-8-ol & 154.25 & 1154 & 1145 & 3.95 \\
\hline Thuj-3-en-10-al & 150.2176 & 1175 & 1181 & 6.53 \\
\hline $\begin{array}{c}\text { 14-hydroxi-4,5- } \\
\text { dihydrocaryophyllene }\end{array}$ & 222.3663 & 1710 & 1706 & 1.72 \\
\hline Monoterpenoids & \multicolumn{3}{|c|}{$92.72 \%$} \\
\hline Sesquiterpenoids & \multicolumn{4}{c}{$1.72 \%$} \\
\hline
\end{tabular}

Both monoterpenoids $(92.72 \%)$ and sesquiterpenoids (1.72\%) were found in the EO of L. dentata. The major compound is 1,8-cineol $(63.25 \%)$. Essential oils of L dentata presented high quantity of monoterpenoids as reported by Chhetri et al. (2015) ${ }^{36}$, Masetto et al. (2011) ${ }^{17}$ and Imelouane et al. (2009) ${ }^{8}$. Essential oil of L. dentata analyzed in Morocco and Tunisia showed high concentrations of 1,8-cineol, 41.3 and $33.5 \%$, respectively ${ }^{36}$. Imelouane et al. (2010) ${ }^{37}$ performed collections of $L$. dentata in Taforalt and Talazart in the east of Morocco and obtained different quantities of oxygenated monoterpenoids, only $5.53 \%$ in the aerial parts. In this study, the major component was $\beta$-pinene $(27.08 \%)$. In addition, seasonal conditions, circadian rhythms, and environmental influences affect the development of the species, producing different chemical composition of $\mathrm{EO}^{17}$.

Considering other species of Lavandula, L. x alardii, a hybrid species (L. dentata x L. latifolia) showed about $60 \%$ of 1,8 -cineole in the EO (Bruni et al., 2006) ${ }^{38}$, whereas, L. luisieri presented $76.68 \%$ (Sanz et al., 2004) ${ }^{39}$. Lavandula angustifolia showed a high content of oxygenated monoterpenes, however their major components were linalool and linalyl acetate as observed in $L$. intermedia and L. vera ${ }^{38,40,43}$. Lavandula latifolia showed the same profile, however the major compounds were linalool and camphor ${ }^{40}$. Lavandula stoechas presented fenchone and camphor as major components ${ }^{41}$. 1,8-Cineole, also known as cineole, eucalyptol or 1,3,3-trimethyl-2oxabicyclo [2.2.2] octane, showed antimicrobial, expectorant, gastroprotective, antiinflammatory, anesthetic, antiseptic, repellent, nematicidal, antispasmodic and other properties. In addition to these activities, it has a non-reactive and non-toxic ${ }^{17,42}$. 


\section{Antimicrobial activity}

When subjected to treatment with the $\mathrm{EO}$ of $L$. dentata, all bacterial species were impacted on their proliferation. For Staphylococcus aureus, minimum inhibitory concentration (MIC) was $54.7 \mu \mathrm{g} \cdot \mathrm{mL}^{-1}$, as well as for Escherichia coli, Candida albicans and Streptococcus pyogenes. For these species, this value $\left(54.7 \mu \mathrm{g} \cdot \mathrm{mL}^{-1}\right)$ was also found for the minimum bactericidal concentration (MBC). For $S$. aureus the value of CBM was higher, $218.8 \mu \mathrm{g} \cdot \mathrm{mL}^{-1}$. The species Pseudomonas aeruginosa showed the least sensitivity to treatment. Thus, it showed no bactericidal concentration, but the treatment with EO of $L$. dentata still could inhibit growth at a concentration of 437.5 $\mu \mathrm{g} \cdot \mathrm{mL}^{-1}$ (Table 2).

Table 2. Minimum Inhibitory Concentration (MIC) in $\mu \mathrm{g} \cdot \mathrm{mL}^{-1}$ and minimum bactericidal concentration (MBC) of the essential oil of Lavandula dentata L. after 24 h of treatment.

\begin{tabular}{|c|c|c|c|c|c|}
\hline Species & $\begin{array}{c}\text { Staphylococcus } \\
\text { aureus }\end{array}$ & $\begin{array}{c}\text { Escherichia } \\
\text { coli }\end{array}$ & $\begin{array}{c}\text { Pseudomonas } \\
\text { aeruginosa }\end{array}$ & $\begin{array}{l}\text { Streptococcus } \\
\text { pyogenes }\end{array}$ & $\begin{array}{l}\text { Candida } \\
\text { albicans }\end{array}$ \\
\hline $\begin{array}{c}\text { MIC } \\
\left(\mu \mathrm{g} \cdot \mathrm{mL}^{-1}\right)\end{array}$ & 54.7 & 54.7 & 437.5 & 54.7 & 54.7 \\
\hline $\begin{array}{c}\mathrm{MBC} \\
\left(\mu \mathrm{g} \cdot \mathrm{mL}^{-1}\right)\end{array}$ & 218.8 & 54.7 & - & 54.7 & 54.7 \\
\hline
\end{tabular}

*Results were obtained in triplicate.

Benbelaid and co-workers (2014) ${ }^{43}$ tested EO of $L$. dentata against two strains of $E$. faecalis (ATCC 29212 and ATCC 49452) and showed a minimum inhibitory concentration of $1.000 \%$ and $0.833 \pm 0.288 \% \mathrm{v} / \mathrm{v}$, respectively. When tested the activity of the EO from L. pedunculata (Mill.) Cav. against Candida albicans ATCC10231, the minimum inhibitory concentration was $2.5 \mu \mathrm{L} \cdot \mathrm{mL}^{-1}$ and $2.9 \mu \mathrm{L} \cdot \mathrm{mL}^{-1}$ for bactericidal concentration minimum of three samples from different locations (Zuzarte et al., 2009) ${ }^{44}$.

Lavandula has a broad spectrum of biological activities, especially their inhibitory effect on the growth of bacteria, including Salmonella, Enterobacter, Klebsiella, E. coli, S. aureus and Listeria monocytogenes ${ }^{45}$. However, when compared with the cited literature, the results obtained in this study with EO of $L$. dentata showed greater antimicrobial potential.

\section{Antioxidant Activity}

\section{Method of the $\mathrm{DPPH} \cdot$ Radical}

The highest antioxidant activity of EO of $L$. dentata obtained by DPPH $\cdot$ method was with the highest concentration tested $\left(20 \mu \mathrm{g} . \mathrm{mL}^{-1}\right)$, resulting $5.7 \pm 1.4 \%$ of activity (Table 3), when compare with the standards, gallic acid and rutin these results are lower than the 96,7 an $97,8 \%$ of the standards, respectively. These results can be compared to those obtained by Mothana and co-workers. (2012) ${ }^{46}$, who performed the test with the same species collected in Yemen and also reported a weak antioxidant activity by DPPH $\bullet$. The concentration of $10 \mu \mathrm{g} \cdot \mathrm{mL}^{-1}$ after $30 \mathrm{~min}$ of incubation showed $1.7 \%$ of activity, approximately the same value obtained in the tests (1.8\%). 
Table 3. Percentage of antioxidant activity by the method of DPPH - at different concentrations in 30 min of incubation. The results represent the mean and the standard deviation. Different letters show significant statistical difference.

\begin{tabular}{c|c|c|c|c}
\hline Concentration $\left(\boldsymbol{\mu g} . \mathbf{m L}^{-1}\right)$ & $\mathbf{2 0}$ & $\mathbf{1 5}$ & $\mathbf{1 0}$ & $\mathbf{5}$ \\
\hline Essential oil & $5,7 \pm 1,4 \%^{\mathrm{a}}$ & $5,2 \pm 0,3 \%^{\mathrm{a}}$ & $1,8 \pm 1,8 \%^{\mathrm{a}}$ & $0,7 \pm 0,7 \%^{\mathrm{a}}$ \\
\hline Gallic acid & $96,7 \pm 1,0 \%^{\mathrm{b}}$ & $96,7 \pm 0,8 \%^{\mathrm{b}}$ & $96,4 \pm 0,3 \%^{\mathrm{b}}$ & $95,8 \pm 0,2 \%^{\mathrm{b}}$ \\
\hline Rutin & $97,9 \pm 0,7 \%^{\mathrm{b}}$ & $97,5 \pm 0,6 \%^{\mathrm{b}}$ & $97,5 \pm 0,6 \%^{\mathrm{b}}$ & $96,5 \pm 1,2 \%^{\mathrm{b}}$ \\
\hline
\end{tabular}

The antioxidant potential is related to the chemical composition of EOs and the differences in EOs chemical composition within species may be due to variations in the edaphic and environmental factors, methods and parts of the plant used for EO extraction and storage conditions ${ }^{8,9,17,47}$.

\section{Phosphomolibdenium Complex}

In the complex reduction of the phosphomolybdenum test, the ascorbic acid has antioxidant activity of $100 \%$, it is the reference substance as recommended in the literature ${ }^{25}$. The relative percentage of antioxidant activity (AAR) of the EO of $L$. dentata was the same in relation to standards rutin and gallic acid (Fig. 1).

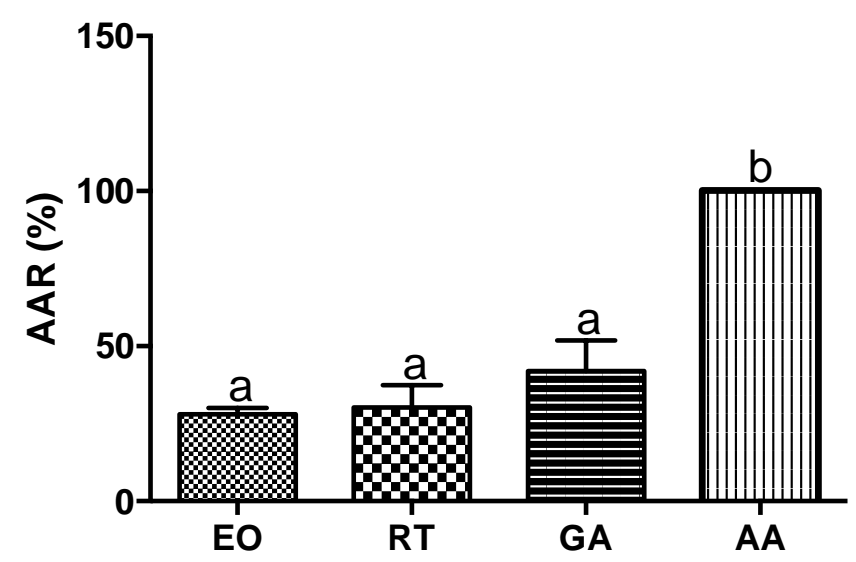

Figure 1. Mean relative antioxidant activity (AAR\%) to ascorbic acid (AA) EO of L. dentata L. by reducing phosphomolybdenum complex method. The error bar represents the standard deviation of antioxidant activity obtained from two independent experiments, performed in triplicate. Different letters represent significant difference obtained by ANOVA analysis followed by post-hoc Tukey tests ( $p$ <0.05). EO: volatile oil; RT: rutin; GA: gallic acid; AA: ascorbic acid.

Essential oil of $L$. dentata had a slight ability to reduce phosphomolybdenum complex with $28.11 \pm 1.95 \%$ AAR, it could be seen that the percentage obtained for oil was lower and statistically different compared with the reference substance, ascorbic acid. However, this test showed no significant difference with rutin and gallic acid standards used and recognized the great potential antioxidant.

\section{ABTS• + Radical}

For dilutions obtained, it was possible to observe a slight antioxidant capacity of EO of

L. dentata. front the highest concentration tested $\left(20 \mu \mathrm{g} . \mathrm{mL}^{-1}\right)$ showed $22.0 \pm 0.6 \%$ of antioxidant activity and the lowest concentration $\left(1.25 \mu \mathrm{g} \cdot \mathrm{mL}^{-1}\right)$ showed $4.4 \pm 3.6 \%$, approximately. Gallic acid and rutin, used as standards, confirmed the great 
antioxidant power as described above, reaching approximately $100.0 \pm 0.4 \%$ and $99.3 \%$ activity, respectively (Table 4 ).

Table 4. Percentage of antioxidant activity in different concentrations of essential oil by cationic radical discoloration method ABTS - +. The results represent the mean and the standard deviation. Different letters show significant statistical difference. (Conc. - concentration).

\begin{tabular}{|c|c|c|c|c|c|c|}
\hline $\begin{array}{c}\text { Conc. } \\
\left(\mu \mathrm{g} . \mathrm{mL}^{-1}\right)\end{array}$ & 20 & 15 & 10 & 5 & 2,5 & 1,25 \\
\hline Essential oil & $\begin{array}{l}22.0 \pm \\
0.6 \%\end{array}$ & $\begin{array}{l}16.3 \pm \\
0.1 \%^{\mathrm{a}}\end{array}$ & $\begin{array}{l}13.8 \pm \\
2.0 \% \%^{\mathrm{a}}\end{array}$ & $\begin{array}{l}9.1 \pm \\
4.0 \%{ }^{\mathrm{a}}\end{array}$ & $\begin{array}{l}5.3 \pm \\
2.2 \%{ }^{\mathrm{a}}\end{array}$ & $\begin{array}{l}4.4 \pm \\
3.6 \%{ }^{\mathrm{a}}\end{array}$ \\
\hline Gallic acid & $\begin{array}{c}100.0 \pm \\
0.4 \% \%^{\mathrm{b}}\end{array}$ & $\begin{array}{c}100.0 \pm \\
0.6 \% \%^{\mathrm{b}}\end{array}$ & $\begin{array}{c}100.0 \pm \\
0.5 \%{ }^{\mathrm{b}}\end{array}$ & $\begin{array}{l}100.0 \pm \\
0.5 \%\end{array}$ & $\begin{array}{l}99.8 \pm \\
0.7 \% \%^{b}\end{array}$ & $\begin{array}{l}99.8 \pm \\
0.3 \%{ }^{\mathrm{b}}\end{array}$ \\
\hline Rutin & $\begin{array}{l}99.3 \pm \\
0.0 \%\end{array}$ & $\begin{array}{l}99.0 \pm \\
0.1 \%\end{array}$ & $\begin{array}{l}98.5 \pm \\
0.2 \%\end{array}$ & $\begin{array}{l}93.9 \pm \\
1.5 \%\end{array}$ & $\begin{array}{l}51.0 \pm \\
3.5 \%{ }^{c}\end{array}$ & $\begin{array}{l}32.8 \pm \\
0.6 \%{ }^{\mathrm{c}}\end{array}$ \\
\hline
\end{tabular}

Several studies have been reported that EO of species of Lavandula have great potential antioxidant such as L. stoechas ${ }^{48,49}$, L. angustifolia ${ }^{50,51}$, L. officinalis ${ }^{52}$ and $L$. pedunculata ${ }^{49}$. Slight antioxidant potential presented by $L$. dentata can be explained by the fact that its EO has many unsaturated compounds and few aromatic compounds with more than one hydroxyl group. Furthermore, the free radical DPPH• does not present enough capacity to be reduced by compounds with few hydroxyls. However, the reduction assay of the phosphomolybdenum complex has a significant value related to an antioxidant activity when compared to the standards. It is known that these complex results from the redox type reactions may be easily reduced by unsaturated substances present in $\mathrm{EO}$ of $L$. dentata ${ }^{53,54}$.

\section{Anatomical Analysis}

The anatomical profile and the histochemical characterization are indispensable parts of all basically pharmacopoeias and are required for identification test for pharmacopoeial compliance ${ }^{55}$. In the present work, anatomical and histochemical characteristics of L. dentata (Fig. 2A) were highlighted. 


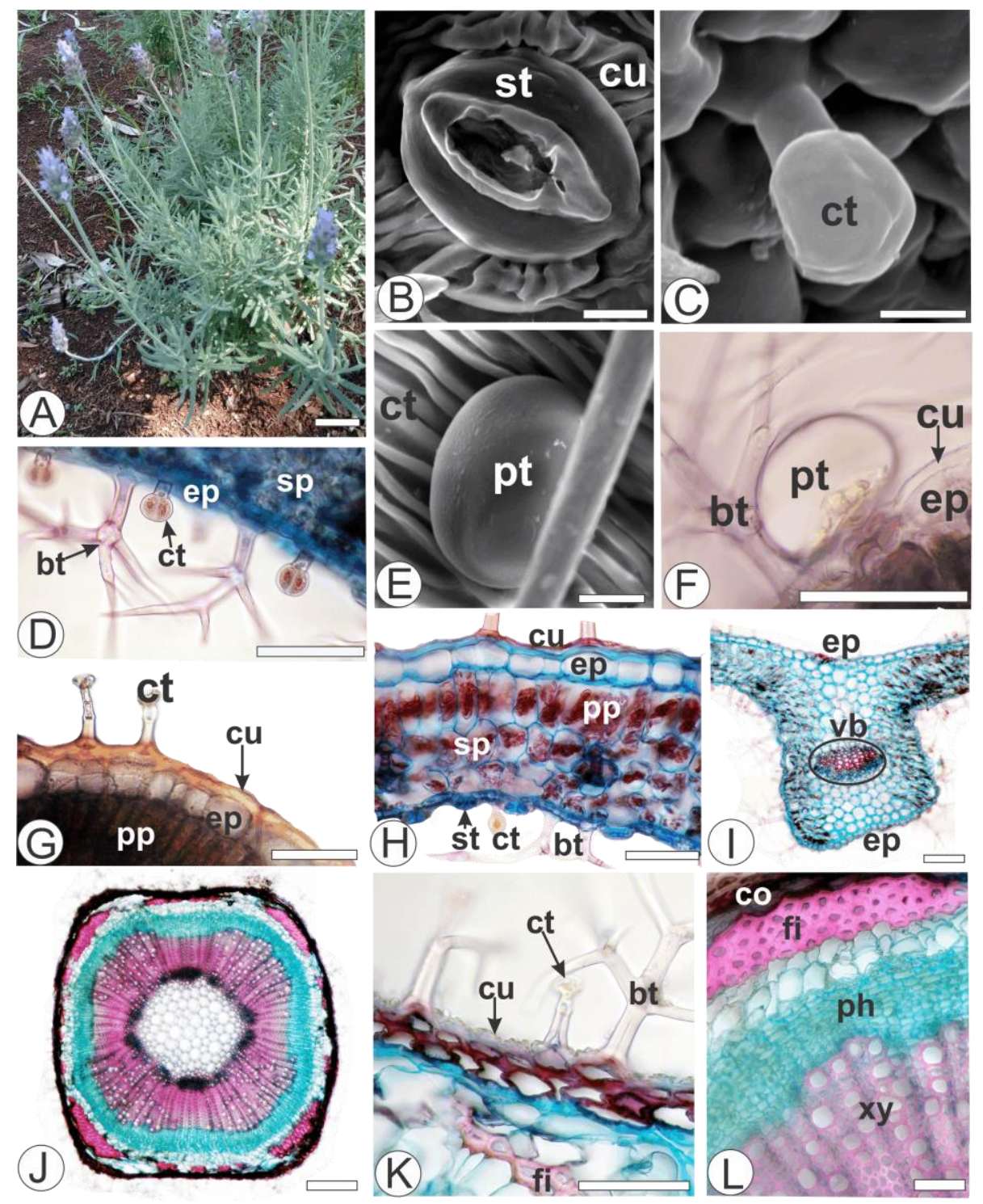

Figure 2. Lavandula dentata L. - Lamiaceae. A. Vegetative and reproductive aerial parts; B, C, E. Front view of abaxial face; D, F, G, H. Cross-section of the blade; I. Cross-section of the midrib; J, K, L. Cross-section of the stem. [branched non-glandular trichome (bt), capitate glandular trichome (ct), collenchyma (co), cuticle (cu), epidermis (ep), fibers (fi), phloem (ph), palisade parenchyma (pp), peltate glandular trichome (pt), spongy parenchyma (sp), stomata (st), vascular bundle (vb), xylem (xy). Bar = 2cm (A); $5 \mu \mathrm{m}(\mathrm{B}, \mathrm{E}) ; 10 \mu \mathrm{m}(\mathrm{C}) ; 50 \mu \mathrm{m}(\mathrm{D}$, F, G, H, K, L); $200 \mu \mathrm{m}(\mathrm{I}, \mathrm{J})$.

The way in which the tissues, elements and cells are located within a plant organ allows the diagnostic fingerprint for purposes of identification ${ }^{56}$. In the present study, the most important features were hypostomatic leaves; diacytic stomata with thin (Figures F, G, H) and striate cuticle tangentially organized around the stomata (Figure B); multicellular and branched non-glandular trichomes (Figures D, F, H, K); capitate glandular trichomes (Figures C, D, G, H, K); peltate glandular trichomes (Figures E, $\mathrm{F}$ ); dorsiventral mesophyll (Figure $\mathrm{H}$ ); flat-convex shape midrib, truncated on the abaxial side (Figure I); one large vascular bundle in the midrib (Figure I); square stem shape (Figure J); angular collenchyma alternated with cortical parenchyma, and sclerenchymatic fibers well-developed in the edges of the stem (Figures J, L).

The histochemical test using Sudan III exposed lipophilic compounds in the capitate and peltate glandular trichomes and striate cuticle (Figure G). The phloroglucin reveled lignin in fibers and in xylem. Phenolic components were evidenced with ferric 
chloride solution in the palisade and spongy parenchymas.

\section{CONCLUSIONS}

The EO of $L$. dentata showed 1,8-cineole as the majority component and high antimicrobial potential against Gram-positive, Gram-negative bacteria and Candida albicans. These findings pave the way for further investigations intended at developing a safe and active antibiotic. The EO showed great antioxidant effect by phosphomolybdenum method, whereas low antioxidant capacity was detected in $\mathrm{DPPH} \cdot$ and ABTS -+ methods. The anatomical characteristics highlighted in this study help in the identification of $L$. dentata and in the differentiation from other species of Lavandula.

\section{REFERENCES}

1- Vanderlinde FA, Rocha FF, Malvar DC, Ferreira RT, Costa EA, Florentino IF, et al. Antiinflammatory and opioid-like activities in methanol extract of Mikania lindleyana, sucuriju. Bras J Pharmacog. 2011; 22(1): 150-156.

2- Souza GS, Castro EM, Soares AM, Pinto JEBP, Resende MG, Bertolucci SKV. Crescimento, teor de óleo essencial e conteúdo de cumarina de plantas jovens de guaco (Mikania glomerata Sprengel) cultivadas sob malhas coloridas. Biotemas. 2011; 24(3): 1-11.

3- Aponte JC, Zin Z, Vaisberg AJ, Castillo D, Málaga E, Lewis WH, et al. Cytotoxic and anti-efective phenolic compounds isolated from Mikania decora and Cremastosperma microcarpum. Planta Med. 2011; 77(14): 1597-1599.

4- Rufatto LC, Finimundy TC, Roesch-Ely M, Moura S. Mikania laevigata: Chemical characterization and selective cytotoxic activity of extracts on tumor cell lines. Phytomedicine. 2013; 20(10): 883-889.

5- Gautam N, Mantha A, Mittal S. Essential oils and their constituents as anticancer agents: a mechanistic view. BioMed Res Int. 2014; 1-23.

6- Sariri R, Seifzadeh S, Sajedi RH. Anti-tyrosinase and antioxidant activity of Lavandula sp. extracts. Pharmacology online. 2009; 3: 319-326.

7- Touati B, Chograni H, Hassen I, Boussaid M, Toumi L, Brahim NB. Chemical composition of the leaf and flower essential oil of Tunisian Lavandula dentata L. (Lamiaceae). Chemistry and Biodiversity. 2011; 8: 1560-1569.

8- Imelouane B, Elbachiri A, Ankit M, Benzeid H, Khedid K. Physico-chemical compositions and antimicrobial activity of essential oil of eastern Moroccan Lavandula dentata. Int J Agric and Biol. 2009; 11(2): 113-118.

9- Upson TM, Grayer RJ, Greenham JR, Williams CA, Al-Ghamdi F, Chan F. Leaf flavonoids as systematic characters in the genera Lavandula and Sabaudia. Biochem Syst Ecol. 2000; 28(10): 991-1007.

10- Duarte MR, Souza DC. Microscopic characters of the leaf and stem of Lavandula dentata L. (Lamiaceae). Microsc Res Techniq. 2014; 77(8): 647-652.

11- Machado MP, Silva ALL, Biasi LA. Effect of plant growth regulators on in vitro regeneration of Lavandula dentata L. shoot tips. Journal of Biotechnology and Biodiversity. 2011; 2(3): 28-31.

12- Bona CM, Biasi LA, Lipski B, Masetto MAM, Deschamps C. Adventitious rooting of auxin-treated Lavandula dentata cuttings. Ciênc Rural. 2010; 40(5): 1210-1213.

13- Bousmaha L, Boti JB, Bekkara FA, Castola V, Casanova J. Infraspecific chemical variability of the essential oil of Lavandula dentata L. from Algeria. Flavour Frag J. 2005; 21(2): 368-372.

14- Soro NK, Majdouli K, Khabbal Y, Zair T. Chemical composition and antibacterial activity of Lavandula species L. dentata L., L. pedunculata Mill. and Lavandula abrialis essential oil from Marocco against foodborne and nosocomial pathogenes. International Journal of Innovation and Applied Studies. 2014; 7(2): 774-781. 
15- Bertocco ARP, Migacz IP, Santos VLP, Franco CRC, Silva RZ, Yunes RA, CechinelFilho V, Budel JM. Microscopic diagnosis of the leaf and stem of Piper solmsianum C. DC. Microsc. Res. Tech. 2017; 80: 831-837.

16- Budel JM, Raman V, Monteiro LM, Almeida VP, Bobek VB, Heiden G, Takeda IJM,

Khan IA. Foliar anatomy and microscopy of six Brazilian species of Baccharis (Asteraceae).

Microsc. Res. Tech. 2018; 81: 1-11.

17- Masetto MAM, Deschamps C, Mógor AF, Bizzo HR. Teor e composição do óleo essencial de inflorescências e folhas de Lavandula dentata L. em diferentes estádios de desenvolvimento floral e épocas de colheita. Revista Brasileira de Plantas Medicinais. 2011; 13(4): 413-421.

18- Figueiredo AC, Pedro LG, Barroso JG, Trindade H, Sanches J, Oliveira C, et al. Pinus pinaster Aiton e Pinus pinea L. Agrotec. 2014; 12: 23-27.

19- Riva, AD. Caracterização morfológica e anatômica de Lavandula dentata e L. angustifolia e estudos de viabilidade produtiva na região centro norte, RS. Dissertação (Mestrado) - Universidade de Passo Fundo, Passo Fundo. 2012.

20- USP. The United States Pharmacopeia. $37^{\text {th }}$ edition. Rockville: United States Pharmacopeial Convention; 2014.

21- NCCLS. Metodologia dos testes de sensibilidade a agentes antimicrobianos por diluição para bacteria de crescimento aeróbico. $6^{\text {th }}$ edition. Wayne, PA: National Committee for Clinical Laboratory Standards; 2003.

22- Duarte MC, Figueira GM, Sartoratto A, Rehder VL, Delarmelina C. Anti-Candida activity of Brazilian medicinal plants. J Ethnopharmacol. 2005; 97(2): 305-311.

23- Yen G, Wu J. Antioxidant and radical scavenging properties of extracts from Ganoderma tsugae. Food Chem. 1999; 65(3): 375-379.

24- Chen CN, Wu CL, Shy HS, Lin JK. Cytotoxic prenylflavanones from Taiwanese Propolis. J Nat Prod. 2003; 66(4): 503-506.

25- Prieto P, Pineda M, Aguilar M. Spectrophotometric quantitation of antioxidant capacity through the formation of a Phosphomolybdenum Complex: specific application to the determination of vitamin E. Anal Biochem. 1999; 269(2): 337-341.

26- Balestrin L, Dias JFG, Miguel OG, Dall'Stella DSG, Miguel MD. Contribuição ao estudo fitoquímico de Dorstenia multiformis Miquel (Moraceae) com abordagem em atividade antioxidante. Braz J Pharmacog. 2008; 18(2): 230-235.

27- Re R, Pellegrini N, Proteggente A, Pannala A, Yang M, Rice-Evans C. Antioxidant activity applying an improved ABTS radical cation decolorization assay. Free Radical Bio Med. 1999; 26(10): 1231-1237.

28- Johansen DA. Plant microtechnique. New York: MacGraw Hill Book; 1940.

29- Berlyn GP, Miksche JP. Botanical microtechnique and cytochemistry. Eames: Iowa State University; 1976.

30- Roeser KR. Die nadel der schwarzkiefer. Massenprodukt und kunstwerk der natur. Mikrokosmos. 1972; 61: 33-36.

31- Foster AS. Practical plant anatomy. $2^{\text {nd }}$ edition. Princeton: D. Van Nostrand; 1949.

32- Sass JE. Botanical microtechnique. $2^{\text {nd }}$ edition. Ames: Iowa State College.

33- Castro HG; Oliveira, LO; Barbosa LCA; Ferreira, FA; Silva DJH; Mosquim, PR; Nascimento, EA. Teor e composição do óleo essencial de cinco acessos de mentrasto. Química nova. 2004; 27(1): 55-57.

34- Serafini LA; Barros NM; Azevedo JL. Biotecnologia na agricultura e na agroindústria. Guaíba: Agropecuária, 2001.

35- Siani AC. Óleos essenciais. Biotecnologia Ciência \& Desenvolvimento. 2000; 2: 38-43.

36- Chhetri BK; Ali NA; Setzer, WN. A Survey of Chemical Compositions and Biological Activities of Yemeni Aromatic Medicinal Plants. Medicines. 2015; 2: 67-92.

37- Imelouane B; Elbachiri A; Wathelet J; Dubois J; Amhamdi H. Chemical composition, cytotoxic and antioxidante activity of the essential oil of Lavandula dentata. World Journal of Chemistry. 2010; 5(2): 103-110.

38- Bruni R; Bellardi MG; Parrella G. Impact of Alfalfa mosaic virus subgroup I and II isolates on terpene secondary metabolism of Lavandula vera D.C., Lavandula $\times$ alardii and eight cultivars of L. hybrida. Physiological and Molecular Plant Pathology. 2006; 68(4-6): 189-197. 
39- Sanz J; Soria AC; García-Vallej MC. Analysis of volatile components of Lavandula luisieri L. by direct thermal desorption-gas chromatography-mass spectrometry. Journal of Chromatography A. 2004; 1024:139-146.

40- Santana O; Cabrera R; González-Coloma A; Sánchez-Vioque R; Mozos-Pascual M; Rodríguez-Conde MF; Laserna-Ruiz I; Usano-Alemany J; Herraiz D. Chemical and biological profiles of the essential oils from aromatic plants of agro zindustrial interest in Castilla-La Mancha (Spain). Grasas y Aceites. 2012; 63(2).

41- Giray S; Kirici S; Kaya DA; Turk M; Sonmez O; Inan M. Comparing the effect of subcritical water extraction with conventional extraction methods on the chemical composition of Lavandula stoechas. Talanta. 2008; 74: 930-935.

42- Vincenzi M; Silanob M; Vincenzic A; Maialettia F; Scazzocchioa B. Constituents of aromatic plants: eucalyptol. Fitoterapia. 2002; 73: 269-275.

43- Benbelaid F, Khadir A, Abdoune A, Bendahou M, Muselli A, Costa J. Antimicrobial activity of some essential oils against oral multidrug-resistant Enterococcus faecalis in both planktonic and biofilm state. Asian Pacific Journal of Tropical Biomedicine. 2014; 4(6): 463472.

44- Zuzarte MR, Dinis AM, Canhoto J, Salgueiro L. Leaf trichomes of Portuguese Lavandula species: a comparative morphological study. Microsc Microanal. 2009; 15(3): 37-38.

45- Prusinowska R, Smigielski KB. Composition, biological properties and therapeutic effects of lavender (Lavandula angustifolia L). A review. Herba Pol. 2014; 60(2): 57-66.

46- Mothana RA, Alsaid MS, Hasoon SS, Al-Mosayib NM, Al-Rehaily AJ, Al-Yahya MA. Antimicrobial and antioxidant activities and gas chromatography mass spectrometry (GC/MS) analysis of the essential oil of Ajuga bracteosa Wall. ex Benth. and Lavandula dentata L. growing wild in Yemen. J Med Plants Res. 2012; 6(15): 3066-3071.

47- Gonçalves S, Romano A. In vitro culture of lavenders (Lavandula spp.) and the production of secondary metabolites. Biotechnol Adv. 2013; 31(2): 166-174

48- Cherrat L, Espina L, Bakkali M, Pagán R, Laglaoui A. Chemical composition, antioxidant and antimicrobial properties of Mentha pulegium, Lavandula stoechas and Satureja calamintha Scheele essential oils and an evaluation of their bactericidal effect in combined processes. Innov Food Sci Emerg. 2014; 22: 221-229.

49- Baptista R, Madureira AM, Jorge R, Adão R, Duarte A, Duarte N, et al. Antioxidant and Antimycotic Activities of Two Native Lavandula Species from Portugal. Evid-Based Compl Alt. 2015; 1-10.

50- Hamad KJ, Al-Shaheen SJA, Kaskoos RA, Ahamad J, Jameel M, Mir SR. Essential oil composition and antioxidant activity of Lavandula angustifolia from Iraq. Int Res J Pharm. 2013; 4(4): 117-120.

51- Hussain AI, Anwar F, Nigam PS, Sarker SD, Moore JE, Rao JR, et al. Antibacterial activity of some Lamiaceae essential oils using resazurin as an indicator of cell growth. LWTFood Science and Technology. 2011; 44(4): 1199-1206.

52- Viuda-Martos M, Mohamady MA, Fernández-Lópes J, El-Razik KAA, Omer EA, PérezAlvarez JA, et al. In vitro antioxidant and antibacterial activities of essentials oils obtained from Egyptian aromatic plants. Food Control. 2011; 22(11): 1715-1722.

53- Boscardin PMD, Farago PV, Nakashima T, Santos PET, Paula JPP. Estudo Anatômico e Prospecção Fitoquímica de Folhas de Eucalyptus benthamii Maiden et Cambage. Latin American Journal of Pharmacy. 2010; 29 (1): 94-101.

54- Blois MS. Antioxidant determinations by the use of a stable free radical. Nature. 1958; 181: 1199-1200.

55- Upton R, Graff A, Jolliffe G, Länger R, Williamson, E. American Herbal Pharmacopoeia: Botanical Pharmacognosy - Microscopic Characterization of Botanical Medicines. Boca Raton: CRC Press. 2011. 